\title{
Traditional practices of the ethnoveterinary plants in the Kaghan Valley, Western Himalayas-Pakistan
}

\author{
Ghazala Shoaib ${ }^{1}$, Ghulam Mujtaba Shah ${ }^{1}$, Nasir Shad ${ }^{2 *}$, Yunus Dogan ${ }^{3}$, Zeeshan Siddique ${ }^{4}$, \\ Abbas Hussain Shah $^{5}$, Muhammad Farooq ${ }^{5}$, Khalid Rasheed Khan ${ }^{5} \&$ Anely Nedelcheva ${ }^{6}$ \\ 1. Department of Botany, Hazara University, Mansehra, Khyber Pakhtunkhwa, Pakistan; ghazalashoaib1987@gmail. \\ com,gmujtabashah72@yahoo.com \\ 2. Key Laboratory of Silviculture, College of Forestry, Jiangxi Agricultural University, Nanchang, 330045, China; dear- \\ botanist@gmail.com \\ 3. Buca Faculty of Education, Dokuz Eylul University, Izmir, Turkey; ynsdgn10@gmail.com \\ 4. Department of Bioscience, University of Wah, Wah Cantt, Pakistan; zsssbio@gmail.com \\ 5. Department of Botany Government Post Graduate College Mansehra, Pakistan; abshah2086@gmail.com, khan4uk@ \\ gmail.com, khalidkhangcmansehra@gmail.com \\ 6. Department of Organic Chemistry and Pharmacognosy, Faculty of Chemistry and Pharmacy, Sofia University "St. \\ Kliment Ohridski”, Sofia, Bulgaria; aneli_nedelcheva@yahoo.com \\ * Correspondence
}

Received 27-V-2020. Corrected 18-VIII-2020. Accepted 16-IX-2020.

\begin{abstract}
Introduction: Indigenous people in a far-flung mountainous area without basic facilities, mainly rely on medicinal plants to cope with various veterinary health problems. Objective: The present study was carried out to explore the traditional knowledge of ethnoveterinary practices in Kaghan Valley, district Mansehra, Western Himalayas-Pakistan. Method: Ethnoveterinary data were collected between February to October 2014 from nine villages of the Kaghan Valley by involving 80 local people include traditional healers using a semistructured interview. Results: A sum of 41 plant taxa of ethnoveterinary medicinal plants was documented for treating livestock ailments. Out of which, herbaceous plants were recorded with high percentage $(27$ species, $65.8 \%$ ). Most of the species were used to treat gastrointestinal diseases (12 taxa), followed by health improvement ( 7 taxa). The widely used part of plants for livestock aliments was the whole plant ( 9 species) followed by leaves ( 7 species), and preparation were paste ( 18 species) followed by powder with 10 species. The highest used values were recorded for Arisaema costatum (0.82), Primula denticulata (0.76), and high relative frequency citations for Berberis lyceum and Dryopteris ramosa with 0.37 each. Among the plant species Skimmia laureola, Thymus linearis and Phytolacca latbenia were among the taxa with cent fidelity level. Conclusion: The flora used in traditional remedies of the valley was found mostly endemic due to excessive utilization. Thus, further chemical investigation, better utilization and conservation of indigenous use of the reported species should be considered for future work.
\end{abstract}

Key words: traditional knowledge; livestock ailments; medicinal plants; Kaghan Valley.

Shoaib, G., Shah, G.M., Shad, N., Dogan, Y., Siddique, Z., Shah, A.H., Farooq, M., Khan, K.R., \& Nedelcheva, A. (2020). Traditional practices of the ethnoveterinary plants in the Kaghan Valley, Western Himalayas-Pakistan. Revista de Biología Tropical, 69(1), 1-11. DOI 10.15517/rbt.v69i1.42021

Plants have been used throughout human evolution for different purposes. The ethnoveterinary covers the utilization of plants by humans to prevent, control, and cure cattle's ailments. The subject of Ethnoveterinary botany
(EVB) or Ethnoveterinary Medicine (EVM) deals with all the traditional techniques applied by humans not only to control the common diseases of domestic animals but also to improve the breeding practices in them (Guzman, 2015). 
The dwellers of remote and mountainous territories preferred ethnoveterinary medicinal plants for the health issues of their livestock (Mathias, 2001). Cattles are one of the primary income sources in the mountain communities and are considered experts in animal rearing, pastoralism, and animal husbandry (Butzer, 1988). The interaction of indigenous plants and domestic animals plays a key role in the subsistence of far-flung human communities providing a wide range of dairy products (Gordon, 2000). Ample literature found on uses of plants by humans such as wild fruit, wild vegetable, fuelwood, ethnomedicine, thatching, timber, etc. The traditional ethnoveterinary knowledge got scientific attention for two decades and reported worldwide, for instance, in East Africa (Dharani et al., 2015), sub-Saharan Africa (Toyang, Wanyama, Nuwanyakpa, \& Diango, 2007), Nigeria (Chafe, Musa, \& Dogara, 2008), Zimbabwe (Matekaire \& Bwakura, 2004), Ethiopia (Yineger, Kelbessa, Bekele, \& Lulekal, 2007), Uganda (Tabuti, Dhillion, \& Lye, 2003), Cameroon (Nfi et al., 2001), Canada (Lans, Turner, Khan, Brauer, \& Boepple, 2007), India (Usha, Rajasekaran, \& Siva, 2016), Europe (Mayer, Vogl, Amorena, Hamburger, \& Walkenhorst, 2014), etc. In Pakistan, few and fragmented literature are present from different parts of the country such as Greater Cholistan desert (Khan, 2009), Southern Punjab (Jabbar, Raza, Iqbal, \& Khan, 2006).

About 258650 species of higher plants have been reported worldwide, and among them, more than $10 \%$ of plants are used for the cure of various diseases as a community scale (Christenhusz \& Byng, 2016). Based on traditional knowledge along with many known drugs (e.g., reserpine, tubocurarine, morphine, and aspirin, etc.), new plants are being studied for their medicinal uses (Rahman et al., 2018). Mountainous communities, particularly of the developing countries, are considered deprived and poorest due to the absence of basic facilities of life. The Northern part of Pakistan is mountainous and encompasses a vast population with no or poor basic facilities. These people endeavor to fulfill all their necessities from mountain agriculture, animal husbandry, medicinal plants, and forest resources (Kiran, Jean-Yves, \& Brigitte, 2011). Domestic animals (goats, sheep, and cows of different varieties) are the major source of income and dairy products for the poor community of the Kaghan Valley. The cultivation of medicinally important plants is limited by the noteworthy deficiency of accessible data on the spread and management of significant species limits (Abbasi et al., 2013). Allopathic drugs for cattle are challenging to access and afford for the people of remote and rural areas of Pakistan (Shinwari, 2010). As a result, the local people highly depend on the herbal remedy to treat many acute and chronic diseases (Abbas, Khan, Alam, Khan, \& Abbasi, 2017). The present work was based on the field works and aimed to document the medicinal plants used in veterinary diseases. The major aim of this study was to make discussion and keeping given limitation in the knowledge in the selected localities; this research was carried out to gather more vital information about ethnoveterinary plants in the Kaghan Valley, Western Himalayas-Pakistan.

\section{MATERIALS AND METHODS}

Study area: Kaghan Valley is situated between $\left(34^{\circ} 14^{\prime}-35^{\circ} 11^{\prime} \mathrm{N} \& 72^{\circ} 49^{\prime}-74^{\circ} 08^{\prime}\right.$ E), lies under the administration of District Mansehra, Pakistan. It is the catchment area of River Kunhar, covering an area of $1627 \mathrm{~km}^{2}$ (Fig. 1). The valley is bounded by Azad Jammu and Kashmir from East and South direction, West by Allai valley, North by Chillas and Gilgit Baltistan. Floristically, the valley falls in the Sino-Japanese region (Takhtajan, 1986). The study area has four ecological zones (temperate, subalpine, alpine, and sub-tropical) with rich forests and high altitudinal mountains of the Himalayan region with averagely $22{ }^{\circ} \mathrm{C}$ minimum and $40{ }^{\circ} \mathrm{C}$ maximum temperature. (Champion, Seth, \& Khattak, 1965; Schickhoff, 1995). The exclusive features of the Kaghan valley are the presence of nomads with a number of herds (Sardar, 2003; Schickhoff, 


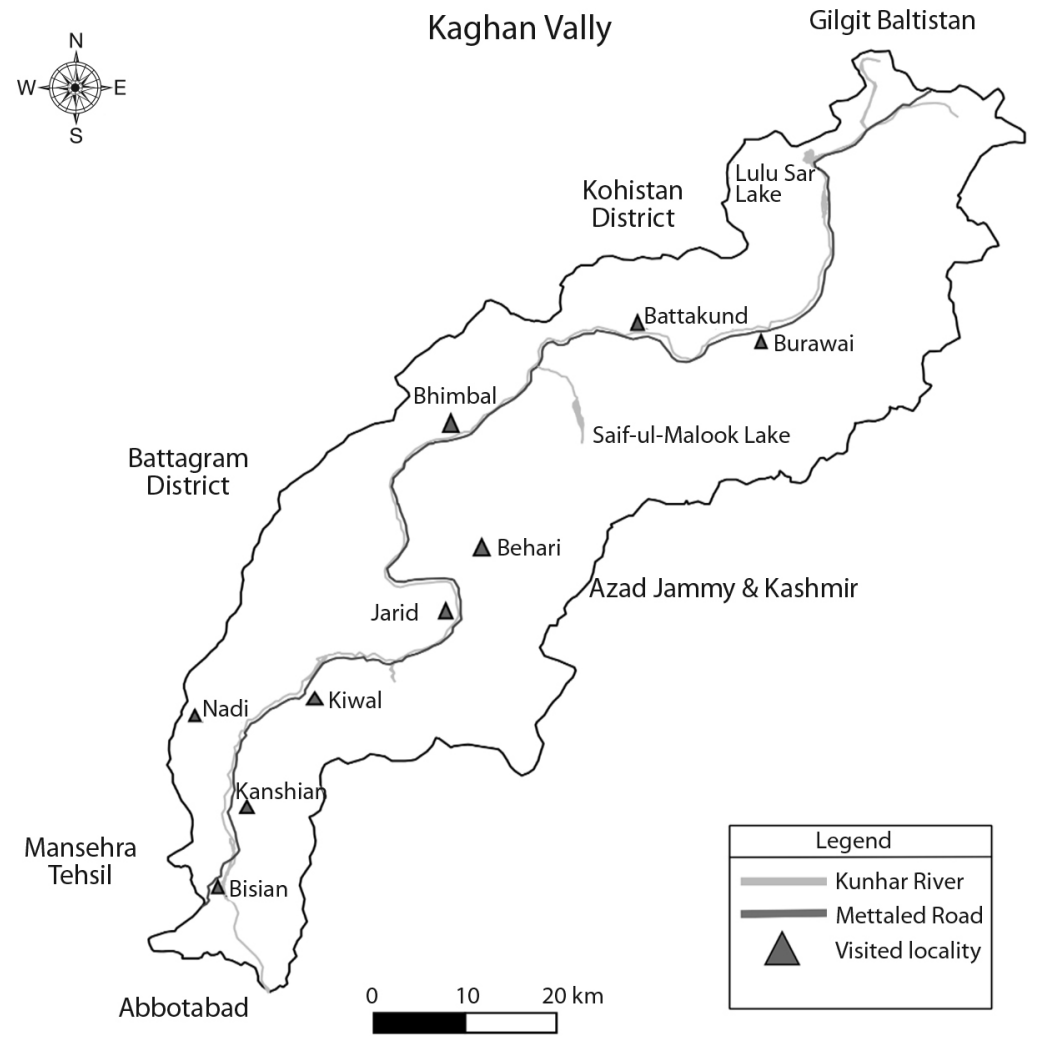

Fig. 1. The study area and visited localities Bank of River Kunhar in Kaghan valley.

1995). The valley is mainly inhabited by the Gujars tribe and Hindko language speakers. It is the famous and common route of nomadic people, and a considerable number of people travel by horses, mules, and donkeys and sometimes by vehicles through the valley as well as stay at high pastures (Siri Payya, Baser, Gitti Das, etc.) in the summer season. During the winter season, they move towards warmer parts of the country like lower Hazara and different parts of the Punjab Province.

Filed survey and data collection: Field trips were arranged consecutively in the study area from February to October 2014 for the collection of ethnoveterinary information and documented plants. Nine villages were selected based on unstructured interviews and group discussions for preliminary valley information. Local people include traditional healers were interviewed directly by semi-structured approach (Martin, 2004). During field trips a total of 80 informants (male and female) between 20-80 years of age were interviewed with inform consents and willing to share their knowledge (Table 1), old people had more information regarding medicinal plants for cattle compared to young people. Socioeconomically, they were farmers, herdsmen, and nomads. Questions on the utility of various plants, their part used, type of preparation, ethnoveterinary uses, and route of administration were asked through questionnaires (Martin, 2004). The recorded taxa and their local veterinary remedies were comparatively assessed with available literature of the country, nomenclature mainly based on Flora of Pakistan (Nasir \& Ali, 1970-2001) for identification. The botanical names and authorities were confirmed following the Angiosperm 
TABLE 1

Knowledge of ethnoveterinary medicinal plants reported by local respondents

\begin{tabular}{llcc} 
Variable & \multicolumn{1}{c}{$\begin{array}{c}\text { Demographic } \\
\text { categories }\end{array}$} & $\begin{array}{c}\text { Number of } \\
\text { informants }\end{array}$ & Percentages \\
Gender & Male & 50 & 62 \\
& Female & 30 & 38 \\
Experience & Traditional healer & 9 & 11 \\
& Local people & 71 & 89 \\
Age groups & $18-40$ & 11 & 14 \\
& $41-60$ & 21 & 26 \\
& Above 60 & 48 & 60 \\
Education & Illiterate & 55 & 69 \\
& Primary & 13 & 16 \\
& Middle & 3 & 4 \\
& Matric and above & 9 & 11 \\
\hline
\end{tabular}

Phylogeny Group IV system (Stevens, 2001), and The Plant List database (TPL, 2013). All the recorded species were properly processed and labeled and submitted to Hazara University, Herbarium.

Data analysis: The used value (UVi) was calculated by the formula proposed by (Phillips \& Gentry, 1993).

$$
\mathrm{UVi}=1 / 4 \sum \mathrm{Ui}=\mathrm{ni}
$$

$U i$ is the number of citations by each informant for the specific species "i" and "ni" is used for the total number of informants interviewed for specific plant species "i". The use value ranges from 0 to 1 .

The Relative Frequency of Citations (RFC) index was used to analyze the traditional practices of the ethnoveterinary medicinal plants and the value of each species recorded in the area (Tardío, Pardo de Santayana, \& Morales, 2006).

$$
\mathrm{RFC}=F C / N
$$

FC is the number of informants who use plant species traditionally, and $\mathrm{N}$ is the total number of informants.
Fidelity level indicates the percentage of informants claiming the use of plant species for the same purpose.

$$
\text { FL }(\%)=\mathrm{Ip} / \mathrm{Iu} \times 100
$$

$I p$ is the number of informants who independently suggested the use of a plant species for a particular disease and $I u$ is the total number of informants who mentioned the same plant for any disease (Alexiades \& Sheldon, 1996).

\section{RESULTS}

Diversity of ethnoveterinary flora: Total 41 plant taxa of 39 genera belonging to 30 families were recorded. Out of which, 34 dicots, 4 monocots, 2 ferns, 1 gymnosperm. Family Polygonaceae was the most widely used family (4 species) followed by Poaceae and Lamiaceae (3 species) each, Apiaceae, Brassicaceae and Ranunculaceae with 2 species each and the other remaining 25 families were with one taxa each (Table 2). Herbs were dominant with 26 species followed by shrubs ( 9 species), trees ( 4 species) and ferns with 2 species. Total of 41 plant species were used to treat twenty different type of disease, grouped in six main categories, among the plant species maximum number of plant species were used to treat gastrointestinal ailments 12 , followed by health improvement 7 , dermal problems 6 , respiratory disorders 5 , urinary tract malfunction and as coolant 1 each (Fig. 2).

Parts used and drug formulation: Local community members used 13 different parts of plants either separately or combined for ethnoveterinary ailments. Out of which, whole plant was widely used part 8 , following by leaves 7 , roots 4 , seeds, grains and bark 2 each, flowers, fronds, fruits and stigma with 1 each. In combination, roots \& rhizomes and leaves $\&$ flowers was the widely used part 2 each, and the other remaining parts with any type of combination were recorded with one part used each. Most of the crude drugs were used in the 


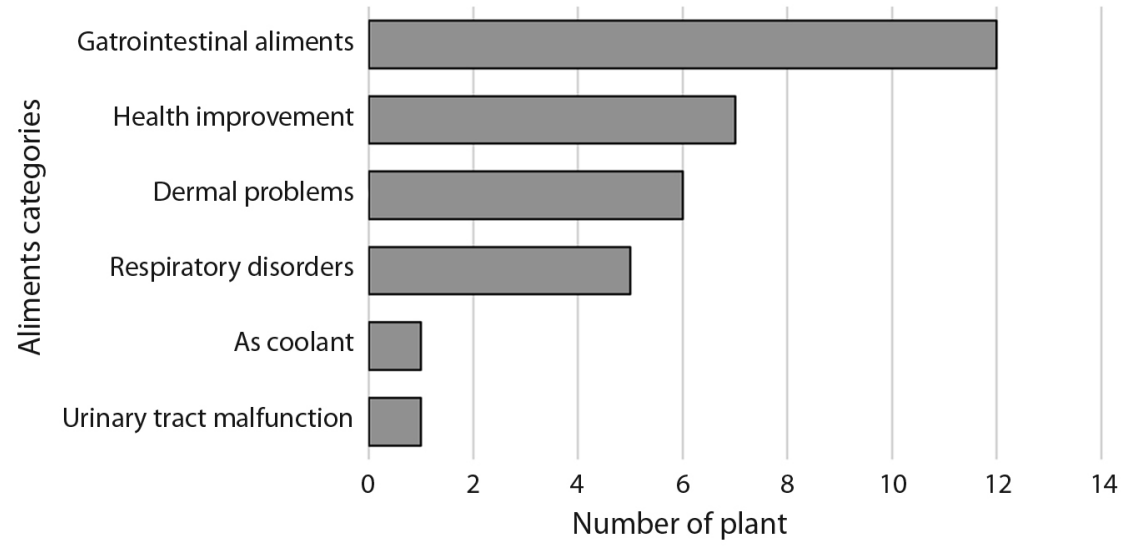

Fig. 2. Major cattle ailments versus the number of plants used.

form of paste (18 species) followed by powder (10 species), decoction (7 species), extract and fried 3 species each (Table 2).

Quantitative analysis: The medicinal plant species with greater use values were Arisaema costatum having (0.82) followed by Primula denticulata (0.76), Paeonia emodi and Geranium wallichianum (0.74) each, Bergenia ciliata (0.71), Foeniculum vulgare and Thymus linearis (0.65) each. While minimum used values of collected medicinal plants was Viscum album (0.14). The RFCs analysis revealed the species with high value were Arisaema costatum, Berberis lyceum, Dryopteris ramosa (0.37) each and Indigofera heterantha (0.35). Skimmia laureola, Thymus linearis, Phytolacca latbenia, Oxalis corniculata, Oryza sativa, Iris hookeriana, Incarvillea emodi and Foeniculum vulgare showed maximum fidelity level (100 $\%)$ as shown in Table 1.

\section{DISCUSSION}

In traditional therapies, the parts and mode of preparation has a significance role in the action of medicinally used plant taxa. The root paste of Aconitum heterophyllum given to cattle against flu and fever. Decoction of fronds and rhizome of Adiantum capillus-veneris is used for treatment of diarrhea. The mashed roots of
Arisaema costatum has therapeutic action in fever, flu and weakness (Abbasi et al., 2013). Fresh leaves of Foeniculum vulgare are given to cattles to treat abdominal pain, indigestion and diarrhea (Jabbar et al., 2006). Flowers and fruit of the same species have been reported as galactagogues and ruminative (Manganelli, Camangi, \& Tomei, 2001). The roots powder of Geranium wallichianum is mixed in water and thick paste is given to cattle for better growth. Paste of fruits and flowers of Heracleum canescens mixed with flour given to cattle for stomach disorder. Incarvillea emodi is effective given in liver inflammation and fever (Ahmad, Ahmad, \& Weckerle, 2015). Oryza sativa boiled with curd and oil and fed to cattle for weakness and lungs infection (Abbasi et al., 2013). The thick paste of Phytolacca latbenia is given to ox and cow for improving health in snowy season. Resin of Pinus roxburghii is applied on skin infections. Also, decoction of needles is used to cure cough and asthma. Root powder of Persicaria bistorta is applied on injuries and boils. Primula denticulata plants infusion used to improve health.

Different workers used different mode of administration to cure the ailments, the use of leaf paste for enteritis, bark powder for helminthic infection, flowers as a tonic and the rind as an astringent and to treat diarrhoea (Karthickeyan \& Gajendran, 2005; Majid et al., 2019). 


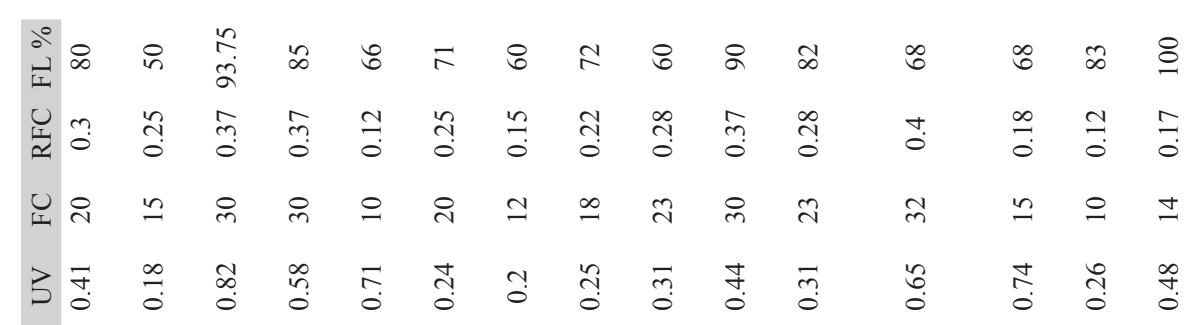

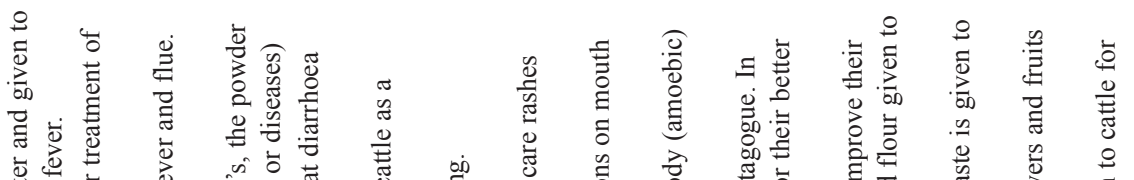

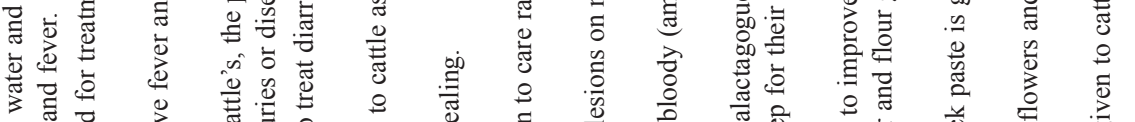

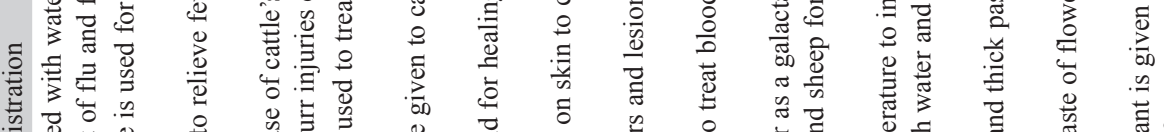

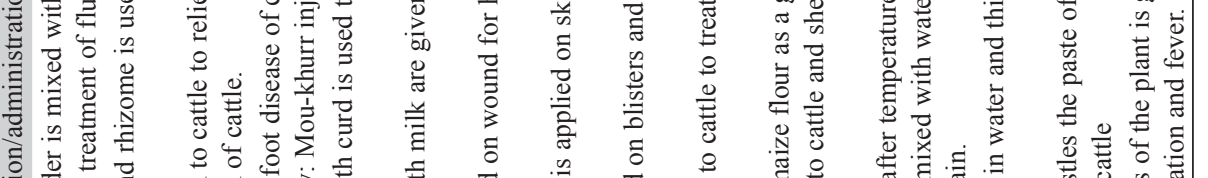

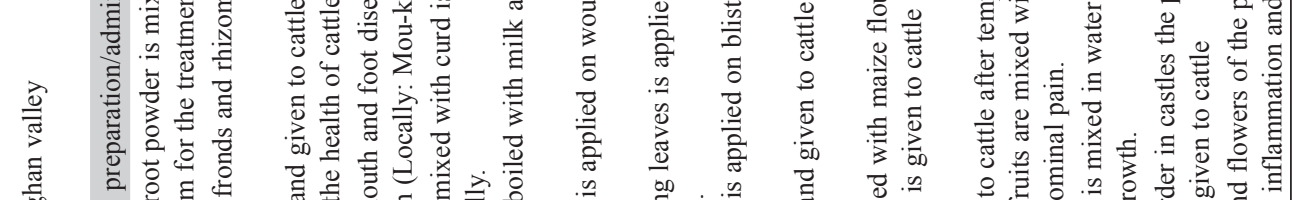

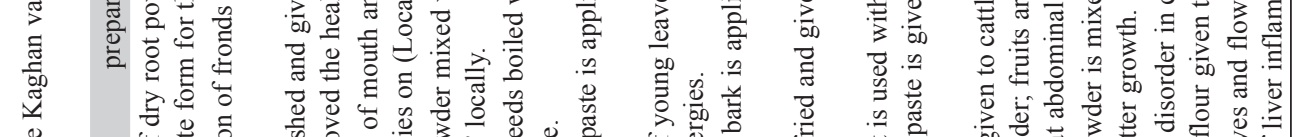

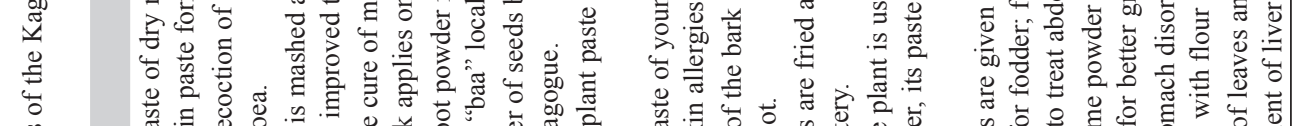

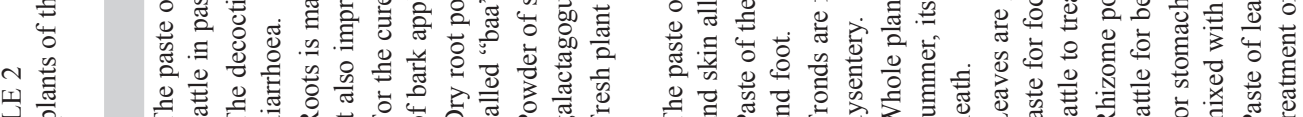

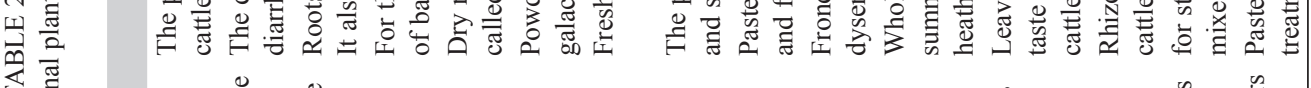

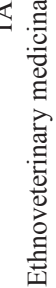

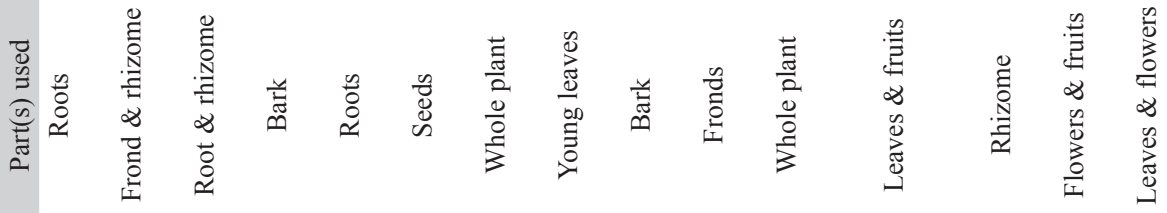

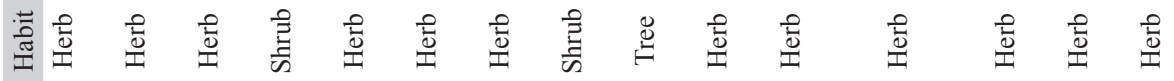

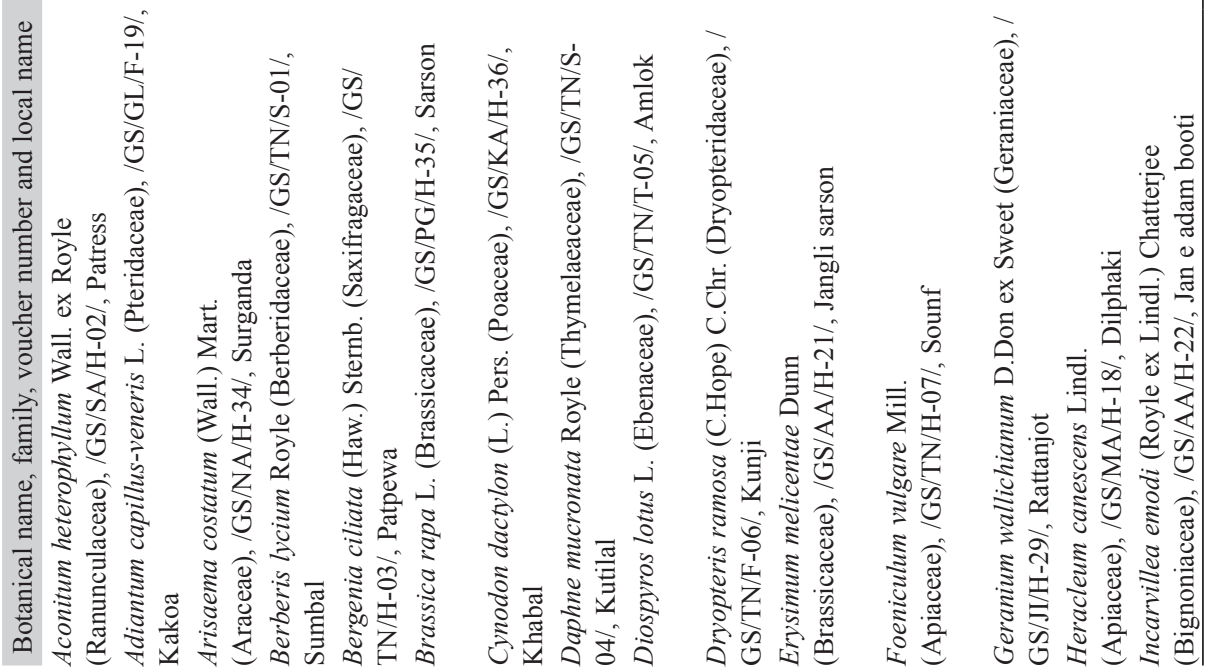




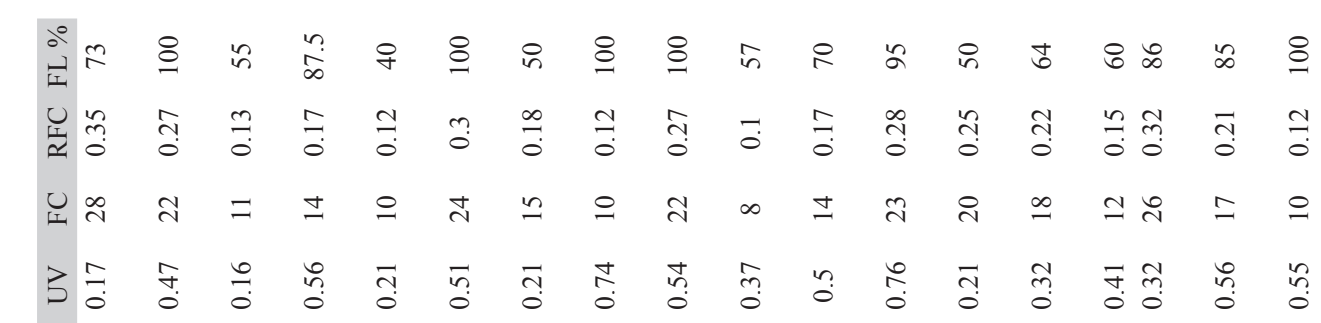

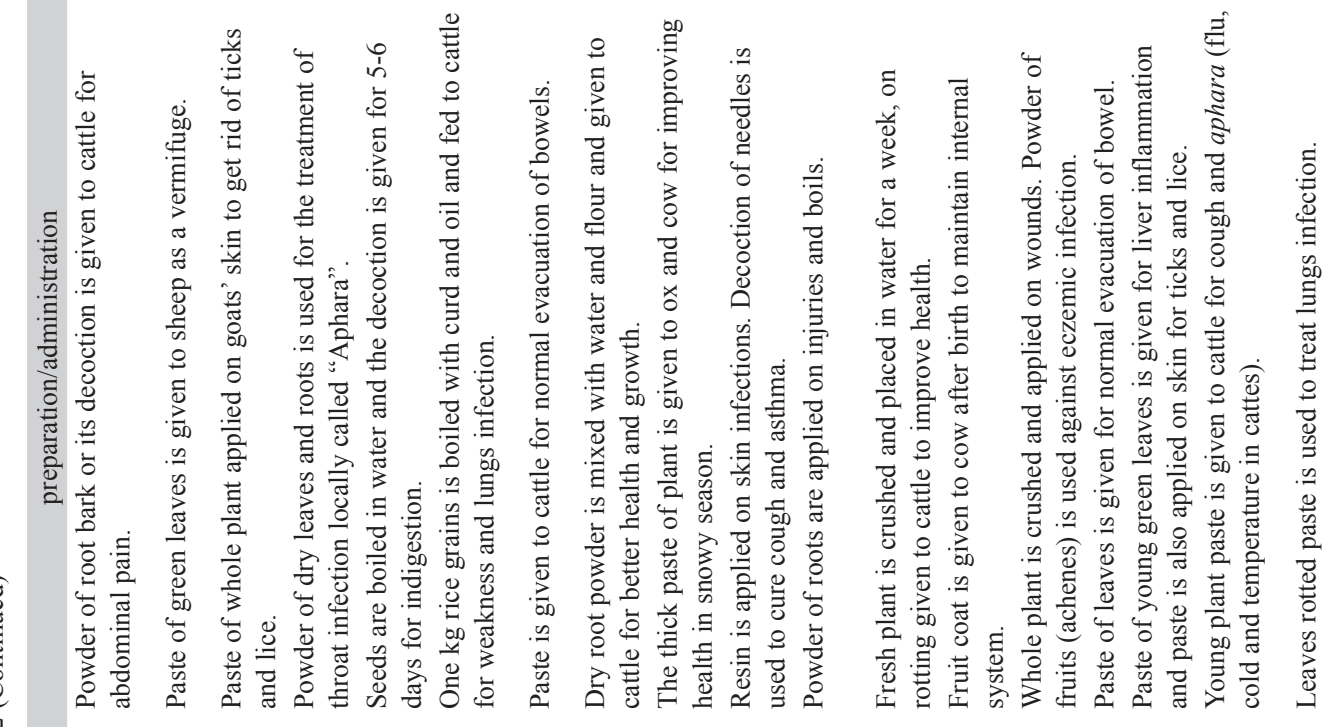

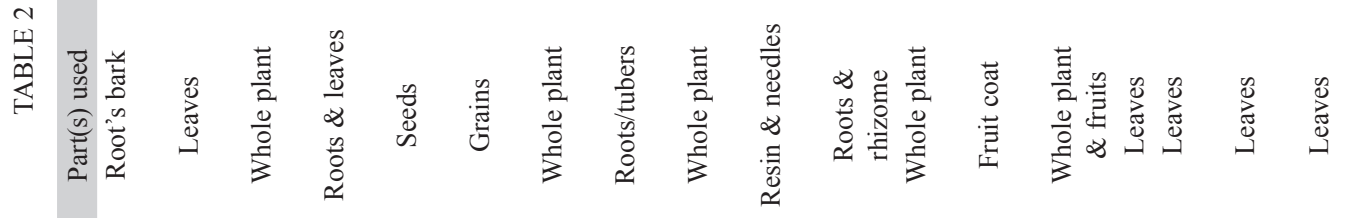

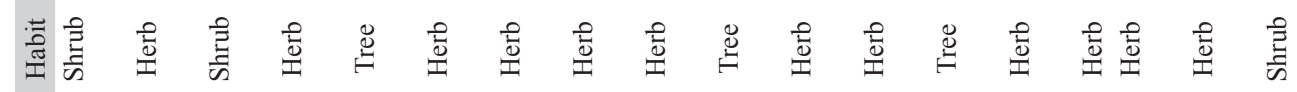

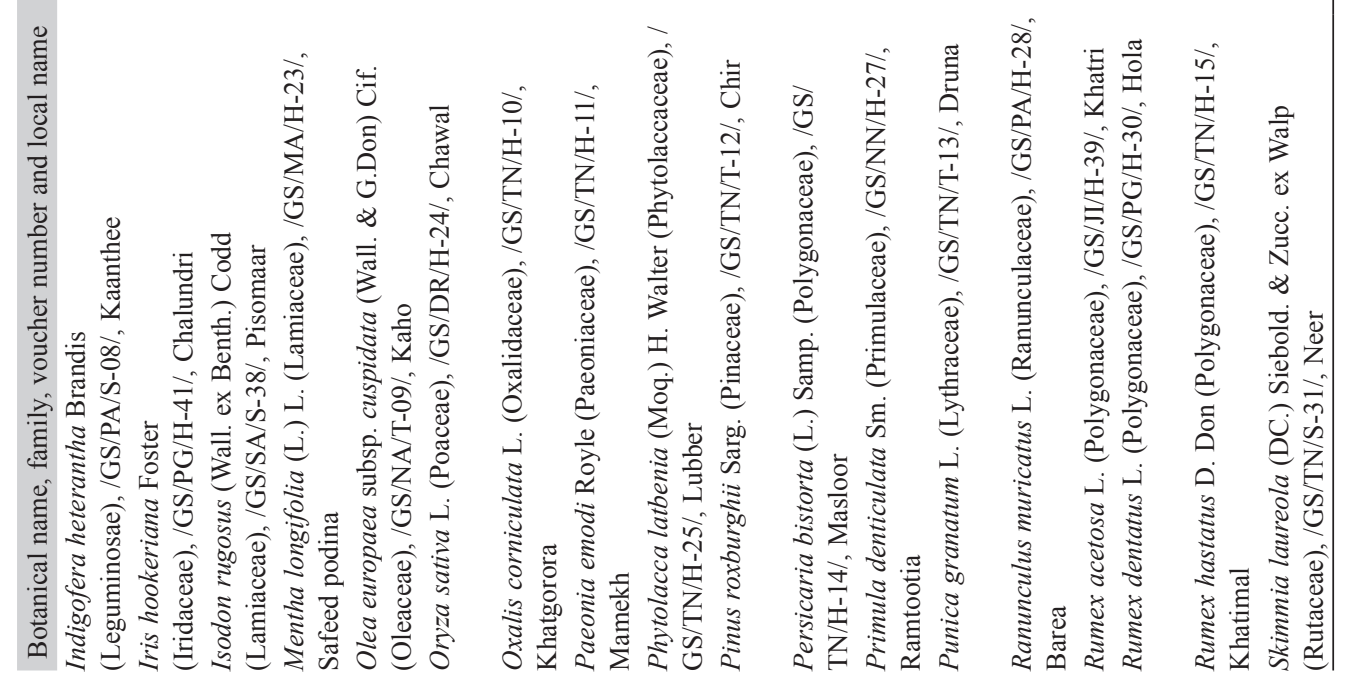




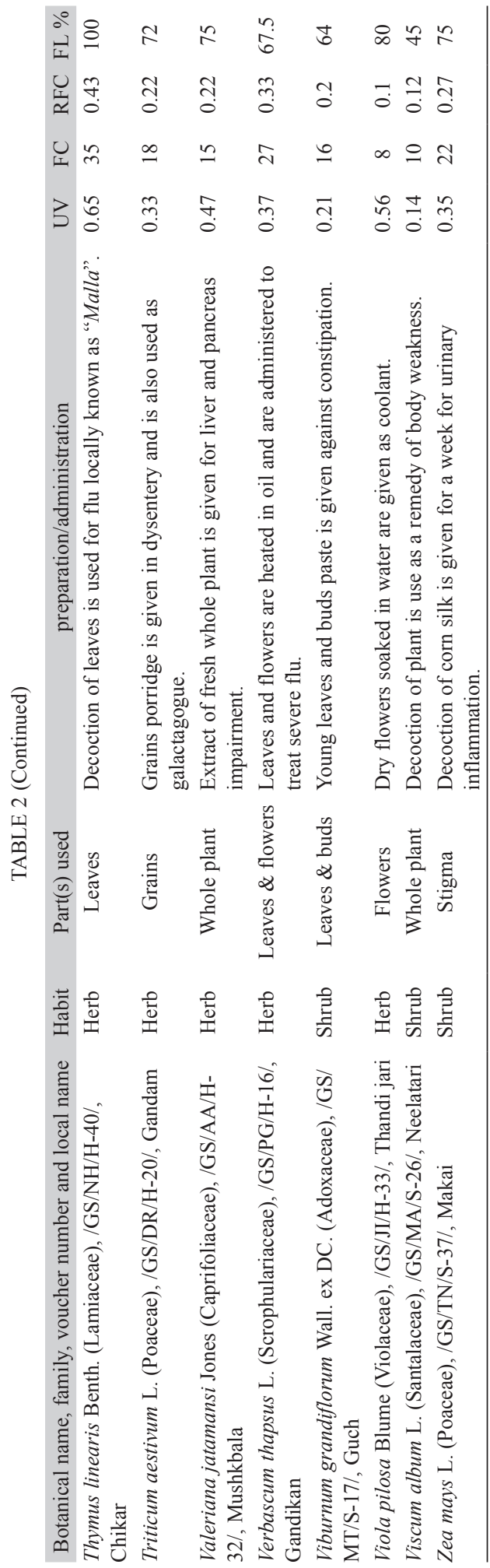

Paste of leaves of Rumex acetosa is given orally for normal evacuation of bowel, relieves liver inflammation and to remove ticks and lice. Root decoction is orally administered for foot and mouth infection (Abbasi et al., 2013). However, the Arial parts are also used for the cure of Scabies. Skimmia laureola leaves rotted paste is used to treat lungs infection. Decoction of leaves of Thymus linearis is used as for flu locally known as "Malla". Triticum aestivum grains porridge is given in dysentery and is also used and orally administered as galactagogue and reported for same uses by Abbasi et al. (2013). Valeriana jatamansi has medicinal action in liver and pancreas impairment. Fresh leaves are used directly or its extract is used, for diarrhea. This plant medicinal use is recently learnt by the locals (Ahmad et al., 2015). Verbascum thapsus is reported to be used as leaf ointment for the treatment of rectal prolapse (Manganelli et al., 2001). Leaves and flowers fried in oil given to treat severe flu. Young buds and leaves of Viburnum grandiflorum paste is given against constipation and flowers of Viola pilosa used as coolant. Decoction of Viscum album is use as a remedy of body weakness and decoction of corn silk of Zea mays is given for a week for urinary inflammation.

Novelty of the study: The current work is the first of its nature in the study area and eleven plant species (Aconitum heterophyllum, Adiantum capillus-veneris, Arisaema costatum, Dryopteris ramose, Incarvilllia emodi, Indigofera heterantha, Iris hookeriana, Olea europaea subsp. cuspidata, Viola pilosa and Valeriana jatamansi) were documented for the first time in Pakistan for their ethnoveterinary practices. These plants were not only different taxonomically but also in ethnoveterinary uses. The ethnoveterinary knowledge diminishes more quickly as compare to the plants important for human health (Farooq et al., 2008; Khan, 2009). The communication disclosed the presence of plant based veterinary knowledge in aged people similar to the studies of Deeba, Muhammad, Iqbal, \& Hussain (2009); Zia ud Din, Zafar, Khan, Jonsson, 
\& Muhammad (2010). This pattern of knowledge may be attributed with decrease interest in domestic animals generation by generation (Nfi et al., 2001). The flora used in traditional remedies of the valley was found mostly endemic due to excessive utilization (Majid et al., 2019). Conservation of indigenous use and better utilization of the reported species should be considered for future work.

Ethical statement: authors declare that they all agree with this publication and made significant contributions; that there is no conflict of interest of any kind; and that we followed all pertinent ethical and legal procedures and requirements. All financial sources are fully and clearly stated in the acknowledgements section. A signed document has been filed in the journal archives.

\section{ACKNOWLEDGMENTS}

We are thankful to the local people and nomads of the Kaghan valley for sharing their ethnoveterinary knowledge, great hospitality, and support. We also thank to Dr. Abid Naeem, Jiangxi University of Traditional Chinese Medicine, China, for their assistance in manuscript revision and improvement.

\section{RESUMEN}

Prácticas tradicionales etnoveterinarias de las plantas en el valle de Kaghan, Himalaya occidentalPakistán. Introducción: Los pueblos indígenas de zonas montañosas lejanas sin facilidades básicas dependen principalmente de las plantas medicinales para afrontar problemas de salud de tipo veterinario. Objetivo: Explorar el conocimiento tradicional en las prácticas etnoveterinarias en el valle de Kaghan, distrito de Mansehra, Himalaya occidental-Pakistán. Métodos: Se recopilaron datos etnoveterinarios mediante una entrevista semiestructurada entre febrero y octubre de 2014 en nueve aldeas del valle de Kaghan, con la participación de 80 habitantes locales, incluidos curanderos tradicionales. Resultados: Se documentó un total de 41 taxones de plantas medicinales etnoveterinarias para el tratamiento de enfermedades del ganado. Se registró un alto porcentaje de plantas herbáceas (27 especies, $65.8 \%$ ). La mayoría de las especies utilizadas han sido para tratar enfermedades gastrointestinales (12 taxones), y mejora de la salud (7 taxones).
Para el tratamiento de enfermedades del ganado, lo más usual fue utilizar la planta entera (9 especies), seguida de las hojas (7 especies), con preparación en pasta (18 especies) y en polvo (10 especies). Las especies registradas con más uso fueron: Arisaema costatum (0.82), Primula denticulata (0.76) y Berberis lyceum y Dryopteris ramosa con la misma alta frecuencia relativa (0.37 cada una). Las especies Skimmia laureola, Thymus linearis y Phytolacca latbenia se reportaron entre los taxones con mayor nivel de fidelidad porcentual. Conclusión: La flora utilizada en los remedios tradicionales del valle de Kaghan fue mayoritariamente endémica. Se propone para trabajos futuros mayor investigación química, y mayor utilización y conservación en las especies de plantas reportadas por los indígenas.

Palabras clave: conocimiento tradicional; dolencias del ganado; plantas medicinales; Valle de Kaghan.

\section{REFERENCES}

Abbas, Z., Khan, S.M., Alam, J., Khan, S.W., \& Abbasi, A.M. (2017). Medicinal plants used by inhabitants of the Shigar Valley, Baltistan region of Karakorum range-Pakistan. Journal of Ethnobiology and Ethnomedicine, 13(1), 1-15.

Abbasi, A.M., Khan, S.M., Ahmad, M., Khan, M.A., Quave, C.L., \& Pieroni, A. (2013). Botanical ethnoveterinary therapies in three districts of the Lesser Himalayas of Pakistan. Journal of Ethnobiology and Ethnomedicine, 9(1), 2.

Ahmad, K., Ahmad, M., \& Weckerle, C. (2015). Ethnoveterinary medicinal plant knowledge and practice among the tribal communities of Thakht-e-Sulaiman hills, West Pakistan. Journal of Ethnopharmacology, 170, 275-283.

Alexiades, M.N., \& Sheldon, J.W. (1996). Selected guidelines for ethnobotanical research: a field manual: New York, USA: New York Botanical Garden.

Butzer, K.W. (1988). Cattle and sheep from Old to New Spain: Historical antecedents. Annals of the Association of American Geographers, 78(1), 29-56.

Chafe, U., Musa, A., \& Dogara, B. (2008). Studies of some health aspects of traditional camel management in Northwestern Nigeria. Blood, 45(21), 20.

Champion, S.H., Seth, S.K., \& Khattak, G. (1965). Forest types of Pakistan. Pakhtunkhwa, Pakistan: Pakistan Forest Institute.

Christenhusz, M.J., \& Byng, J.W. (2016). The number of known plants species in the world and its annual increase. Phytotaxa, 261(3), 201-217.

Deeba, F., Muhammad, G., Iqbal, Z., \& Hussain, I. (2009). Appraisal of ethno-veterinary practices used for different ailments in dairy animals in peri-urban areas 
of Faisalabad (Pakistan). International Journal of Agriculture and Biology, 11, 535-541.

Dharani, N., Yenesew, A., Aynekulu, E., Tuei, B., Jamnadass, R., \& Dawson, I.K. (2015). Traditional ethnoveterinary medicine in East Africa. A Manual on the Use of Medicinal Plants. Nairobi, Kenya: The World Agroforestry Centre (ICRAF).

Farooq, Z., Iqbal, Z., Mushtaq, S., Muhammad, G., Iqbal, M.Z., \& Arshad, M. (2008). Ethnoveterinary practices for the treatment of parasitic diseases in livestock in Cholistan desert (Pakistan). Journal of Ethnopharmacology, 118(2), 213-219.

Gordon, I. (2000). Plant-animal interactions in complex plant communities: from mechanism to modelling. In G. Lemaire, J. Hodgson, A. Moraes, C. Nabinger, \& P.C.F. Carvalho (Eds.), Grassland Ecophysiology and Grazing Ecology (pp. 191-207). Oxon, England: $\mathrm{CAB}$ International.

Guzman, L.S. (2015). Non-experimental Validation of the Effectiveness of Ethno-Veterinary Botanical Medicine (EVB-M) Materials Used in the Municipality of Echague Isabela. Journal of Agricultural Technology, 11(8), 2377-2389.

Jabbar, A., Raza, M.A., Iqbal, Z., \& Khan, M.N. (2006). An inventory of the ethnobotanicals used as anthelmintics in the southern Punjab (Pakistan). Journal of Ethnopharmacology, 108(1), 152-154.

Karthickeyan, S., \& Gajendran, K. (2005). Indigenous technical know-how in the healthcare of domestic animals. Pretoria, South Africa: CSIR.

Khan, F.M. (2009). Ethno-veterinary medicinal usage of flora of Greater Cholistan desert (Pakistan). Pakistan Veterinary Journal, 29(2), 75-80.

Kiran, H., Jean-Yves, G., \& Brigitte, H. (2011). Understanding mountain poverty in the hindu kush-himalayas: Regional report for Afghanistan, Bangladesh, Bhutan, China, India, Myanmar, Nepal, and Pakistan. Kathmandu, Nepal: International Centre for Integrated Mountain Development (ICIMOD).

Lans, C., Turner, N., Khan, T., Brauer, G., \& Boepple, W. (2007). Ethnoveterinary medicines used for ruminants in British Columbia, Canada. Journal of Ethnobiology and Ethnomedicine, 3, 1-22.

Majid, A., Ahmad, H., Saqib, Z., Rahman, I.U., Khan, U., Alam, J., ... Ali, N. (2019). Exploring threatened traditional knowledge; ethnomedicinal studies of rare endemic flora from Lesser Himalayan region of Pakistan. Revista Brasileira de Farmacognosia, 29(6), 785-792.

Manganelli, R.U., Camangi, F., \& Tomei, P. (2001). Curing animals with plants: traditional usage in Tuscany (Italy). Journal of Ethnopharmacology, 78(2-3), 171-191.
Martin, G. (2004). Ethnobotany. A methods manual. People and plants conservation series. $W W F$. London, UK: Earthscan Publications.

Matekaire, T., \& Bwakura, T. (2004). Ethnoveterinary medicine: A potential alternative to orthodox animal health delivery in Zimbabwe. International Journal of Applied Research in Veterinary Medicine, 2(4), 269-273.

Mathias, E. (2001). Introducing ethnoveterinary medicine. Bergisch Gladbach, Germany: Source.

Mayer, M., Vogl, C.R., Amorena, M., Hamburger, M., \& Walkenhorst, M. (2014). Treatment of organic livestock with medicinal plants: a systematic review of European ethnoveterinary research. Complementary Medicine Research, 21(6), 375-386.

Nfi, A., Mbanya, J., Ndi, C., Kameni, A., Vabi, M., Pingpoh, D., ... Moussa, C. (2001). Ethnoveterinary medicine in the Northern Provinces of Cameroon. Veterinary Research Communications, 25(1), 71-76.

Phillips, O., \& Gentry, A.H. (1993). The useful plants of Tambopata, Peru: I. Statistical hypotheses tests with a new quantitative technique. Economic Botany, 47(1), 15-32.

Rahman, I.U., Afzal, A., Iqbal, Z., Ijaz, F., Ali, N., \& Bussmann, R.W. (2018). Traditional and ethnomedicinal dermatology practices in Pakistan. Clinics in Dermatology, 36(3), 310-319.

Sardar, M.R. (2003). Agro-Pastoral Production Systems Of High Altitude Pastures, Upper Kaghan Valley, NWFP, Pakistan. In J.M. Suttie \& S.G. Reynolds (Eds.), Transhumant Grazing Systems in Temperate Asia. Roma, Italy: Food and Agriculture Organization of the United Nations.

Schickhoff, U. (1995). Himalayan forest-cover changes in historical perspective: A case study in the Kaghan valley, northern Pakistan. Mountain Research and Development, 15(1), 3-18.

Shinwari, Z.K. (2010). Medicinal plants research in Pakistan. Journal of Medicinal Plants Research, 4(3), 161-176.

Stevens, P.F. (2001). onwards. Angiosperm Phylogeny Website. Version 9. Recuperado de http://www. mobot. org/MOBOT/research/APweb

Tabuti, J.R., Dhillion, S.S., \& Lye, K.A. (2003). Ethnoveterinary medicines for cattle (Bos indicus) in Bulamogi county, Uganda: plant species and mode of use. Journal of Ethnopharmacology, 88(2-3), 279-286.

Takhtajan, A. (1986). Floristic regions of the world. Berkeley, USA: University of California Press.

Tardío, J., Pardo de Santayana, M., \& Morales, R. (2006). Ethnobotanical review of wild edible plants in Spain. Botanical Journal of the Linnean Society, 152(1), 27-71. 
Toyang, N.J., Wanyama, J., Nuwanyakpa, M., \& Diango, S. (2007). Ethnoveterinary medicine. A practical approach to the treatment of cattle diseases in subSaharan Africa. The Netherlands: Agromisa Foundation and CTA, Wageningen.

Usha, S., Rajasekaran, C., \& Siva, R. (2016). Ethnoveterinary medicine of the Shervaroy Hills of Eastern Ghats, India as alternative medicine for animals. Journal of Traditional and Complementary Medicine, 6(1), 118-125.
Yineger, H., Kelbessa, E., Bekele, T., \& Lulekal, E. (2007). Ethnoveterinary medicinal plants at bale mountains national park, Ethiopia. Journal of Ethnopharmaco$\log y, 112(1), 55-70$.

Zia ud Din, S., Zafar, I., Khan, M.N., Jonsson, N., \& Muhammad, S. (2010). Documentation of ethnoveterinary practices used for treatment of different ailments in a selected hilly area of Pakistan. International Journal of Agriculture and Biology, 12(3), 353-358. 